\title{
TOLERANSI KEBERAGAMAAN SEKTE IBÂDÎYYAH ERA DINASTI RUSTAMÎYAH
}

\author{
Ahmad Choirul Rofiq \\ Sekolah Tinggi Agama Islam Negeri Ponorogo, Indonesia \\ E-mail: rofiq8377@yahoo.co.id
}

\begin{abstract}
Similar to any theological sect, the Kharijite has split into many smaller groups. Usually all these groups were characterized as extreme factions who used violence in the pursuit of their purposes. However, the factual evidence proved that there was Ibadite which was considered as the most moderate group. The Ibadites tend to avoid extreme behaviour. Due to their moderation, they successively ascended to power. The example of their remarkable achievement was the Rustamid Dynasty in Maghreb from 160-296H (776-909AD). As far as the research is concerned, unfortunately, there is no comprehensive records on the Rustamid accomplishment. The Rustamids reigned their plural society with different backgrounds in ethnicity, nationality, and religion. By doing so, the Rustamids could generate harmonious life in the entire territory under their government. Besides, the Rustamids have achieved an extraordinary civilization. The Rustamid tolerance was based on their ideology. The moderate Ibadite doctrine inspired the Rustamids to become tolerant to their various people. Actually, Indonesians with their diversity could also achieve high civilization such as what the Rustamid has achieved in terms of religious tolerance.
\end{abstract}

Keywords: Ibadite doctrine, Rustamids, tolerance, moderation.

\section{Pendahuluan}

Klaim negatif tentang aliran Khawârij sebagai kelompok penyuplai para teroris yang melakukan perlawanan terhadap pemerintahan yang sah banyak didiskusikan oleh para akademisi. ${ }^{1}$ Selain klaim tersebut,

1 Fetima Mernissi, Islam and Democracy: Fear of the Modern World, terj. Mary Jo Lakeland (Cambridge: Perseus Publishing, 2002), 27-28; Ira H Lapidus, A History of Islamic Societies (Cambridge: Cambridge University Press, 1989), 59-60; dan Jeffrey T. 
kajian mengenai pelaksanaan kekuasaan politik Khawârij sangat jarang dijumpai. Dalam hal ini penulis akan mengkaji eksistensi pemerintahan Rustamîyah yang bermazhab Ibâdîyah dengan mengkaji lebih komprehensif karya Ibn al-Ṣaghîr, sejarawan yang hidup pada masa Dinasti Rustamîyah, dalam kitabnya Akbbâr al-A'immah alRustamîyn, sebagai rujukan utama.

Sejarah menyebutkan bahwa golongan Khawârij terbagi menjadi berbagai kelompok. Al-Isfarâynî mencatat dua puluh sekte Khawârij. ${ }^{2}$ Tentunya, jumlah sekte sebanyak itu bukan merupakan jumlah baku dan permanen. Barangkali setiap penulis mempunyai pendapat yang berbeda, mungkin lebih sedikit atau lebih banyak. Misalnya, Ishậq b. 'Aqîl 'Azûz al-Makkî yang menyebutkan 27 kelompok Khawârij.' Menurut al-Shahrastanî di dalam al-Milal wa al-Nihal, terdapat beberapa kelompok utama di kalangan Khawârij, antara lain: Azâriqah, Najadât, Șufrîyah, dan Ibâdîyah. Adapun kelompokkelompok lainnya merupakan pecah kongsi dari beberapa kelompok mayoritas tersebut. ${ }^{4}$ Kondisi semacam ini sangat memudahkan penguasa untuk menumpas dan menghancurkan pemberontakan mereka. Perpecahan Khawârij dipicu oleh perbedaan persepsi di antara mereka yang terkadang lainnya saling mengklaim kafir. ${ }^{5}$

Di antara kelompok Khawârij tersebut terdapat kelompok yang dipandang sebagai kelompok paling moderat, yakni Ibâḍ̂yah. ${ }^{6}$

Kenney, Muslim Rebels: Kharijites and the Politics of Extremism in Egypt (Oxford: Oxford University Press, 2006), 23.

${ }^{2}$ Dua puluh kelompok Khawârij itu, antara lain: Muhakkimah, Azâriqah, Najadât, Șufrîyah, 'Ajâridah, Ibâḍ̂yah, Khâzimîyah, Shu'aybîyah, Shaybânîyah, Ma‘badîyah, Rashîdîyah, Mukarramîyah, Ḥamzîyah, Ibrâhîmîyah, Wâqifìyah, Ḥafṣ̂yah, Hậrithîyah, Yazîdîyah, Aṣhâb Tấáah lâ yurâd bihâ Allâh, dan Maymûnîyah. Lihat Abû al-Muzaffar al-Isfarâynî, al-Tabsîr fì al-Dîn wa Tamyî́z al-Firqah al-Nâjiyah 'an alFiraq al-Hâlikin (Beirut: Dâr al-Kutub al-'Ilmîyah, 1988), 23-24.

${ }^{3}$ Ishâa b. 'Aqîl 'Azûz al-Makkî, al-Firaq al-Islâmîyah (Beirut: Dâr Ibn Hạm, 1995), 17-23.

${ }^{4}$ Abû al-Fath Muḥammad b. 'Abd al-Karîm al-Shahrastânî, al-Milal wa al-Niḥal, Vol. 1 (Beirut: Dâr al-Kutub al-'Ilmîyah, t.th.), 107.

${ }^{5}$ Muḥammad Abû Zahrah, Târîkh al-Madhâhib al-Islâmîyah fî al-Siyâsah wa al-'Aqâ'id, Vol. 1 (Mesir: Dâr al-Fikr al-'Arabî, 1946), 80; dan Mạ̣mûd Ismâ'îl, al-Ḥarakât alSirriyah fí al-Islâm (Kairo: Ru'yah, 2006), 32.

6 Abû Zahrah, Târikeh, Vol. 1, 89, 'Âmir al-Najjâr, al-Khawârij: 'Aqîdah wa Fiker wa Falsafah (Kairo: Dâr al-Ma'ârif, 1990), 165; dan Nâyif Mạ̣mûd Ma'rûf, al-Khawârij fî al-'Assr al-Umawî (Beirut: Dâr al-Ṭalî‘ah, 1994), 239. 
Penyebutan Ibâdîyah biasanya dipergunakan oleh masyarakat Afrika Utara, sedangkan Abâdîyah dipakai oleh masyarakat Oman. ${ }^{7}$ Pada umumnya, nama Ibâdîyah (Abâdîyah) dihubungkan dengan seorang tokoh bernama 'Abd Allâh b. Ibâḍ (w. 86 H/705 M), padahal telah ada tokoh-tokoh lain yang mempunyai peranan signifikan bagi perkembangan mazhab Ibâdîyah sebelum Ibn Ibâd, di antaranya ialah Abû Bilâl Mirdâs al-Tamîmî (w. 61 H/680 M) dan Jâbir b. Zayd al'Umânî (w. 93 H/711 M). Mirdâs merupakan pemimpin kelompok dari sempalan Khawârij yang berhaluan moderat. Menurutnya, kegiatan penyebaran ideologi mereka pasca-kekalahan dalam perang Nahrawân di tangan Khalifah 'Alî b. Abî Tâlib hendaknya dilakukan secara rahasia untuk menghindari tekanan-tekanan keras yang dilancarkan pemerintahan Umawiyah. Kelompok yang dibentuk oleh Mirdâs ini menyebut diri mereka dengan nama Ahl al-Da'wah. Ia menyeru kepada para pengikutnya supaya tidak memerangi orangorang yang berbeda pendapat dengan mereka, kecuali apabila orangorang tersebut secara terang-terangan memaksa mereka untuk mengadakan peperangan. ${ }^{9}$ Jâbir adalah tokoh Khawârij Ibâdîyah yang berasal dari Oman. Ia mempunyai hubungan yang sangat erat dengan Mirdâs. Peranan Jâbir bagi kelangsungan Ibâdîyah semakin menonjol setelah Mirdâs meninggal. ${ }^{10}$

Secara historis kelahiran Ibâdîyah tidak dapat dilepaskan dari fenomena kemunculan kelompok Khawârij lainnya. Hubungan Ibâdîyah dan Khawârij merupakan hubungan kesejarahan pada masa lampau. Ibn Ibâḍ bahkan pada awalnya dalam jangka waktu tertentu adalah pengikut Nâfí b. al-Azraq (w. $65 \mathrm{H} / 685 \mathrm{M}$ ), pemimpin Khawârij Azâriqah. ${ }^{11}$ Sumber-sumber selain Ibâdîyah sering menghubungkan penamaan Ibâdîyah dengan sosok Ibn Ibâd, sedangkan para penulis dari kelompok Ibâḍ̂yah sendiri menegaskan

\footnotetext{
7 Aḥmad Muḥammad Aḥmad Jalî, Dirâsah 'an al-Firaq wa Târikkh al-Muslimîn: alKhawârij wa al-Shî‘ah (Riyad: Markaz al-Malik Fayṣal li al-Buhûth wa al-Dirâsât alIslâmîyah, 1988), 74.

8 'Amr Khalîfah al-Nâmî, Dirâsât 'an al-Ibâdîyah (Beirut: Dâr al-Gharb al-Islâmî, 2001), 33; dan 'Adûn Jahlân, al-Fikr al-Siyâsî 'inda al-Ibâdîyah (Seeb: Maktabat alDâamirî, t.th.), 19.

9 'Iwạ̣ Muḥammad Khalîfât, al-Ușûl al-Târîkhîyah li al-Firqah al-Ibâdîyah (Seeb: Wizârat al-Turâth al-Qawmî wa al-Thaqâfah, 1994), 5-6.

${ }^{10}$ Ibid., 20-24.

11 'Âmir al-Najjâr, al-Ibâdîyah (Kairo: Maktabah al-Thaqâfah al-Dînîyah, 2004), 9.
} 
Jâbir b. Zayd (w. 93 H/711 M) sebagai pendiri sejati kelompok Ibâdîyah. Ibn Ibậ sering berpedoman pada pandangan dan pertimbangan Jâbir ketika hendak mengambil tindakan dan menyampaikan pendapat yang mewakili kelompok Ibâdîyah, meskipun usianya sebenarnya lebih senior dari Jâbir. Bisa dikatakan bahwa posisi Jâbir adalah pemimpin spiritual bagi kelompok Ibâdîyah. Ia berhasil menetapkan formulasi pemikiran Ibâdîyah sehingga terlihat berbeda dari mazhab-mazhab lainnya. Adapun Ibn Ibâd adalah figur yang bertanggung jawab terhadap kegiatan penyebaran ideologi Ibâḍ̂yah dan pengiriman juru dakwah Ibâdîyah ke berbagai pelosok negara Islam. Ia berulang-ulang menemui Jâbir untuk berguru dan mengadakan diskusi serius dalam mengkaji permasalahan keagamaan. ${ }^{12}$ Pembinaan terhadap perjuangan Ibâdîyah sesungguhnya berada di tangan Jâbir. ${ }^{13}$ Karena pandangan dan sikapnya cenderung moderat terhadap pemerintah Umawîyah, maka Ibn Ibâḍ juga berpandangan dan bersikap moderat pula.

Berkat perencanaan yang tertata sangat rapi dan penuh kecermatan, akhirnya perjuangan gerakan Ibâdîyah dapat berhasil meraih kesuksesan. Hal itu terbukti dengan keberhasilan penyebaran Ibâdêyah melintasi wilayah di luar Bashrah sebagai pusat dan titik awal gerakan Ibâdîyah. Wilayah-wilayah yang dapat dicapai gerakan Ibâḍ̂yah, antara lain: Hadramaut, Yaman, Oman, Tanzania, Libya, Tunisia, dan Aljazair, bahkan sebagian di antaranya mampu mendirikan pemerintahan Ibâdîyah. Misalnya, pemerintahan di Hadramaut dan Yaman pada masa Dinasti Umawiyah tahun $129 \mathrm{H}$ (746 M), pemerintahan di Oman yang berlangsung dua periode, yakni tahun 132-134 H (750-752 M) dan 177-280 H (793-893 M) pada masa Dinasti 'Abbâsîyah, dan pemerintahan Rustamîyah (Rustumîyah) di Maghrib yang ditaklukkan oleh Dinasti Fâtimîyah. ${ }^{14}$

12 Muhammad Șâlih Nâṣir dan Sultân b. Mubârak al-Shaybânî, Mu'jam A lâm alIbâdîyah min al-Qarn al-Awwal al-Hijrî ilâ al-'Aṣr al-Hậạir: Qism al-Mashriq (Beirut: Dâr al-Gharb al-Islâmî, 2006), 267.

${ }^{13}$ Khalîfât, al-Us sul, 9.

14 Ibid., 51-52; Fârûq 'Umar Fawzî, al-Imâmah al-Ibâdîyah fî̀ 'Umân (Oman: Jâmi'ah Âli Bayt, 1997), 5; Muḥammad 'Îsâ al-Harîrî, al-Dawlah al-Rustamîyah bi al-Maghrib alIslâmî: Hạârâtuhâ wa 'Alâqatuhâ al-Khârijîyah bi al-Maghrib wa al-Andalus (Kuwait: Dâr al-Qalam, 1987), 185; Ibn 'Idhârî, al-Bayân al-Mughrib fì Akbbâr al-Andalus wa alMaghrib, Vol. 1 (Leiden: E.J. Brill, 1948), 197; dan 'Alî Yahyâ Mu'ammar, al-Ibâdîyah fì Mawkỉ al-Târîkh, Vol. 2 (Seeb: Maktabat al-Dâmirî, 2008), 7. 
Pengangkatan 'Abd al-Raḥmân b. Rustam sebagai imâm pertama Dinasti Rustamiyah terjadi pada tahun $160 \mathrm{H}$ atau $776 \mathrm{M},{ }^{15}$ sedangkan keruntuhan Dinasti Rustamîyah terjadi pada bulan Shawwâl $296 \mathrm{H}$ bertepatan dengan bulan Juni 909 M ketika Yaqzân b. Abî al-Yaqzân dikalahkan oleh Dinasti Fâtimîyah di bawah komando Abû 'Abd Allâh al-Shî̀1. ${ }^{16}$ Signifikansi Dinasti Rustamîyah dipertegas dengan stabilitas pemerintahan Dinasti Rustamîyah yang berlangsung selama lebih dari satu abad di wilayah kekuasaannya yang meliputi sebagian Maghrib Awsat (Aljazair) dan Maghrib Adnâ (Libya). ${ }^{17}$ Kemajuan ekonomi dan intelektual diaktualisir dengan baik, sehingga Tahert yang menjadi pusat pemerintahan Rustamîyah disebut sebagai 'Trâq alMaghrib atau al-'Trâq al-Saghîr. ${ }^{18}$ Namun, sebagian besar literatur sejarah Islam kurang menaruh perhatian secara mendalam terhadap perkembangan peradaban Islam pada masa Dinasti Rustamîah. Kebanyakan literatur hanya menampilkan kajian sepintas terhadap Dinasti Rustamiyah. Kenyataan ini sungguh bertolak belakang jika dibandingkan dengan kajian-kajian terhadap dinasti lainnya dari sekte Sunnî maupun Shî‘ah.

\section{Para Pemimpin Rustamîyah}

Berikut ini adalah pemaparan mengenai para pemimpin yang menjalankan pemerintahan Rustamîyah.

1. 'Abd al-Raḥmân b. Rustam (160-171 H/776-787 M)

Mengenai silsilah 'Abd al-Raḥmân b. Rustam tidak dijumpai keterangan sedikit pun di dalam Akhbâr al-A'immah al-Rustamîŷn. Ibn al-Ṣaghîr hanya menyebutkan adanya beberapa orang sekte Ibâdîyah yang berkumpul di Tahert bersama 'Abd al-Raḥmân yang bersepakat memilih 'Abd al-Raḥmân menjadi imâm yang mempunyai kewajiban menyelesaikan persoalan-persoalan mereka, misalnya menolong masyarakat yang dizalimi, menghukum pelaku kejahatan, mendistribusikan zakat yang terkumpul, dan lain-lain. Penunjukan terhadap 'Abd al-Raḥmân disebabkan dirinya tidak mempunyai suku dan keluarga besar yang dapat melindunginya. Menurut masyarakat Ibâḍ̂yah, mereka akan mudah menggulingkan 'Abd al-Raḥmân

\footnotetext{
15 al-Ḥarîrî, al-Dawlah, 94.

${ }^{16}$ Ibn 'Idhârî, al-Bayân, Vol. 1, 197.

17 al-Ḥarîrî, al-Dawlah, 231-232.

18 Sulaymân Bâshâ al-Bârûnî, al-Az̧hâr al-Riyâtîyah A'immah al-Ibâdîyah, Vol. 2 (Oman: Salțanah 'Umân, 1987), 49; dan al-Ḥarîrî, al-Dawlah, 234.
} 
seandainya ia terbukti melakukan deviasi dalam memimpin disebabkan ketiadaan suku atau keluarga yang mampu membela dan melindunginya. ${ }^{19}$

Sesungguhnya, nasab 'Abd al-Raḥmân dapat dirujuk pada sosok Bahrâm yang silsilahnya sampai kepada raja-raja Persia. Bahrâm, kakek 'Abd al-Raḥmân, menjadi mawlâ Khalifah 'Uthmân di Madinah pada waktu itu. Rustam meninggal ketika melaksanakan ibadah haji ke Mekah bersama istrinya dan 'Abd al-Raḥmân. Istri Rustam menikah lagi dengan seorang pria dari Qayrawan, sehingga 'Abd al-Raḥmân yang masih sangat kecil itu ikut ayah tirinya ke sana. 'Abd al-Raḥmân tumbuh di Qayrawan yang saat itu menjadi pusat ilmu pengetahuan dan telah mendapatkan sentuhan dakwah Khawârij Ibâdîyah melalui Salamah b. Sa'd. Setelah tertarik dengan ajaran-ajaran Ibâdîyah yang cenderung moderat, ia kemudian menjadi pengikut Ibâḍiyah. ${ }^{20}$

Perjalanan kehidupan 'Abd al-Raḥmân berikutnya ialah bergabung dalam delegasi pelajar yang terpilih untuk dikirim ke Bashrah supaya menuntut ilmu kepada pemimpin utama Ibâdîyah, Abû 'Ubaidah Muslim, dan para tokoh Ibâdîyah di sana. Ia bersama Abû al-Khațâb berjuang membentuk pemerintahan Ibâdîyah. Walaupun menemui banyak kendala, ia akhirnya menemukan Tahert sebagai lokasi yang tepat untuk menegakkan kekuasaan politik. Setelah 'Abd al-Rahmân dibaiat menjadi pemimpin Ibâdîyah, maka langkah permulaan yang dilakukannya adalah pembangunan Tahert sebagai pusat pemerintahan. Menurut penyunting buku Akbbâr al-A'immah alRustamîyîn, lokasi Tahert yang dibangun kembali oleh 'Abd al-Raḥmân dan orang-orang Ibâdîyah ini berjarak sekitar 9 atau 10 kilometer arah Barat dari Tahert (Tiaret) pada masa sekarang atau sekitar 430 kilometer arah Barat daya dari Algiers, ibukota Aljazair. ${ }^{21}$

Dalam pembangunan Tahert, Ibn al-Ṣagîr menyebutkan, 'Abd alRaḥmân menerima bantuan finansial dari masyarakat Ibâdîyah yang hidup di Bashrah. Bantuan tersebut dikarenakan adanya informasi luas mengenai keadilan seorang pemimpin Ibâdîyah bernama 'Abd alRaḥmân yang menjalankan kepemimpinan dengan penuh keadilan dan kezuhudan. Sebelum bantuan yang telah terkumpul itu

${ }^{19}$ Ibid., 29-30.

${ }^{20}$ al-Harîrî, al-Dawlah, 74-78.

21 Ibn al-Ṣaghîr, Akhbâr al-A'immah al-Rustamîyîn (Beirut: Dâr al-Gharb al-Islâmî, 1986), 28-29; dan http://en.wikipedia.org/wiki/Tiaret (diakses 6 Agustus 2012). 
disampaikan, masyarakat Ibâdîyah di Bashrah menetapkan persyaratan bahwa apabila informasi yang mereka dengar tentang keutamaan 'Abd al-Raḥmân terbukti kebenarannya, maka hendaknya bantuan segera diberikan. Namun, apabila kebenaran informasi tersebut tidak terbukti, maka hendaknya bantuan segera dikembalikan kepada para pendermanya. Mereka pun berangkat ke Tahert dan berhenti di sebuah musala. Kemudian mereka bertanya kepada warga yang ditemui untuk menunjukkan rumah 'Abd al-Raḥmân. Sesampainya di sana dan setelah memperkenalkan diri masing-masing, mereka dijamu dengan sebaik-baiknya. Ketika melakukan perjamuan di rumah yang sangat sederhana itu, 'Abd al-Rahmmân tampil dengan pakaian yang juga sangat sederhana, sehingga semakin menunjukkan ketakwaan dan kezuhudannya. Setelah perjamuan, mereka pun mengutarakan maksud kedatangannya ke Maghrib. Mereka menyebutkan bantuan finansial dari hasil sumbangan masyarakat Ibâdîyah Mashriq. Ketika perbincangan sedang berlangsung, tiba-tiba datang waktu menunaikan ibadah salat, maka 'Abd al-Raḥmân mengajak mereka supaya ikut salat berjamaah dan bertemu dengan semua masyarakat untuk memberitahukan tujuan mereka. Setelah menunaikan salat, mereka memperkenalkan diri dan menginformasikan bantuan yang mereka bawa dari Mashriq. ${ }^{22}$

Musyawarah dilakukan di antara tokoh-tokoh dari tiap suku Ibâḍ̂yah di Maghrib untuk membahas persoalan itu. Musyawarah tersebut membagi harta bantuan itu menjadi tiga bagian untuk dibelanjakan sesuai kebutuhan, yakni sepertiga untuk membeli kuda, sepertiga untuk belanja perlengkapan perang, dan sepertiga terakhir untuk disedekahkan kepada para fakir miskin. Harta bantuan itu dibagi secara langsung menjadi tiga bagian di hadapan para utusan Ibâdîyah Mashriq. Setelah proses pembagian itu tuntas, mereka kembali ke kawasan Mashriq. Sesudah harta itu dipergunakan sebagaimana mestinya, maka keadaan masyarakat Tahert mulai berubah. Pertahanan keamanan mereka semakin kokoh.

Pendirian bangunan-bangunan dan optimalisasi pertanian dijalankan demi kemakmuran masyarakat umum secara menyeluruh. Berkat pelaksanaan pembangunan itu, kesejahteraan masyarakat bertambah meningkat dan denyut kehidupan Tahert semakin semarak. Keadaan yang demikian itu dilihat langsung oleh semua orang dari

${ }^{22}$ Ibn al-Ṣaghîr, Akhbâr, 32-34. 
berbagai kawasan yang datang ke Tahert untuk melakukan aktivitas perdagangan atau yang lainnya. Selain itu, para pendatang malah merasa nyaman tinggal di Tahert sesudah menyaksikan sifat 'Abd alRaḥmân yang memimpin pemerintahan dengan penuh keadilan terhadap semua warga dan kejujuran dalam menunaikan amanat, baik urusan yang menyangkut kepentingan pribadi maupun yang berhubungan dengan permasalahan masyarakat luas. Konsekuensinya, populasi warga Tahert semakin bertambah dan beraneka ragam sesuai banyaknya jumlah pendatang yang berdomisili di sana. ${ }^{23}$

Setelah pemerintahan 'Abd al-Raḥmân berjalan tiga tahun, masyarakat Ibâdîyah Mashriq berkunjung lagi ke Tahert untuk menyampaikan bantuan finansial kembali dalam jumlah yang lebih banyak daripada sebelumnya. Bantuan itu dikirimkan secara rahasia pula agar tidak diketahui oleh musuh-musuh Ibâdîyah yang ingin menghancurkan Ibâdîyah. Rombongan ini sangat terkejut sesampai di Tahert ketika menyaksikan keadaan kehidupan masyarakat Tahert telah berubah drastis. Pembangunan di mana-mana, pertanian maju, masyarakat sejahtera, dan kemakmuran merata. Mereka bertanya kepada para warga Tahert mengenai keadaan 'Abd al-Raḥmân. Semua warga menceritakan kehidupan 'Abd al-Raḥmân yang tetap seperti keadaan sebelumnya ketika mereka memberikan bantuan pertamanya. Rombongan itu menemui 'Abd al-Raḥmân untuk menyampaikan bantuan yang mereka himpun dari masyarakat Ibâdîyah Mashriq. Pada saat pertemuan, 'Abd al-Raḥmân bertanya kepada mereka apakah di wilayah mereka masih terdapat orang fakir miskin yang membutuhkan bantuan.

Ketika mereka menyebutkan adanya orang-orang yang masih membutuhkan di tempat mereka, 'Abd al-Raḥmân lantas mengajak mereka ke masjid. Sesudah menunaikan salat, para utusan tadi diminta menunjukkan bantuan yang dibawa di hadapan masyarakat Tahert dan mengatakan sebagaimana yang telah mereka katakan kepada 'Abd alRaḥmân. ${ }^{24}$ 'Abd al-Raḥmân menanyakan pendapat masyarakatnya tentang kiriman bantuan saudara-saudara mereka dari Mashriq tersebut. Mereka menyerahkan keputusan kepada 'Abd al-Raḥmân, pemimpin mereka. 'Abd al-Raḥmân memutuskan untuk mengembalikan harta itu kepada masyarakat Ibâḍ̂yah Mashriq.

${ }^{23}$ Ibid., 34-36.

${ }^{24}$ Ibid., 37-39. 
Alasannya, dahulu masyarakat Tahert bersedia menerima bantuan Ibâḍ̂yah Mashriq disebabkan mereka dalam keadaan sangat membutuhkan. Karena keadaan mereka telah membaik dan bertambah makmur, mereka tidak bersedia menerima bantuan itu dan mengembalikannya kepada masyarakat Ibâdîyah Mashriq. Kondisi kehidupan masyarakat Tahert semakin sejahtera berkat kepemimpinan 'Abd al-Raḥmân yang penuh keadilan, kezuhudan, dan perhatian terhadap semua warga yang berada di Tahert. ${ }^{25}$ Setelah melaksanakan kepemimpinan selama sekitar sebelas tahun dengan keberhasilan yang sangat gemilang dan ditandai oleh peningkatan kesejahteraan rakyatnya, pemerintahan 'Abd al-Raḥmân berakhir pada tahun $171 \mathrm{H}$ $(787 \mathrm{M})$ ketika ia wafat. ${ }^{26}$

2. 'Abd al-Wahhâb b. 'Abd al-Raḥmân (171-211 H/787-826 M)

Sebelum 'Abd al-Raḥmân meninggal, ia telah membentuk tim pemilihan yang terdiri dari tujuh orang untuk melakukan pemilihan terhadap seorang di antara mereka sebagai pengganti 'Abd al-Raḥmân dalam menjalankan pemerintahan, di mana pemilihan tersebut menahbiskan 'Abd al-Wahhâb sebagai pengganti ayahnya. Dalam pelaksanaan pembaiatan itu terdapat interupsi yang dilakukan oleh Yazîd b. Fandîn, di mana ia mengatakan bahwa pembaiatan terhadap 'Abd al-Wahhâb hendaknya diadakan dengan persyaratan tertentu, yaitu 'Abd al-Wahhâb tidak boleh menetapkan suatu keputusan, kecuali telah mendapatkan persetujuan dari tim tertentu yang mendampingi 'Abd al-Wahhâb. Persyaratan itu segera ditolak Mas'ûd yang menegaskan bahwa seorang pemimpin pemerintahan tidak diikat oleh persyaratan tertentu, kecuali berpegang kokoh kepada sumber otoritatif, al-Qur'an dan hadîth Rasulullah. Penolakan Mas'ûd tersebut juga diamini oleh orang-orang yang hadir di sana, sehingga Ibn Fandîn dan pengikutnya terdiam. Akhirnya, 'Abd al-Wahhâb dibaiat atas persetujuan sebagian besar masyarakat. Mas'ûd adalah orang pertama yang memberikan pembaiatan kepada 'Abd al-Wahhâb. ${ }^{27}$

Setelah suksesi pemerintahan selesai, perkembangan berikutnya menunjukkan adanya perpecahan dalam masyarakat Ibâdîyah di Tahert. Ibn Fandîn terus menggalang dukungan anti-pemerintahan 'Abd al-Wahhâb. Orang-orang yang mendukung Ibn Fandîn ini

\footnotetext{
${ }^{25}$ Ibid., 40-41.

26 al-Harîrî, al-Dawlah, 108.

27 al-Bârûnî, al-Ažhâr, Vol. 2, 148-150.
} 
disebut dengan al-Nukkâr (para penentang 'Abd al-Wahhâb). ${ }^{28}$ Puncak perseteruan di antara dua kelompok tersebut terjadi pada tahun $171 \mathrm{H}(787 \mathrm{M})$ yang ditandai dengan meletusnya peperangan antara masyarakat pendukung pemerintah dan penentang pemerintah. Meskipun perang sempat dihentikan setelah gencatan senjata tercapai, namun perang berlanjut dan kemenangan berada di pihak pemerintah dengan kematian Ibn Fandîn. Walaupun begitu, kekisruhan politik belum juga mereda. Para pendukung Ibn Fandîn melakukan pembunuhan terhadap Maymûn b. 'Abd al-Wahhâb. Mereka ditumpas oleh pasukan pemerintah yang langsung dipimpin oleh putera Maymûn. ${ }^{29}$ Persoalan berikutnya yang dihadapi 'Abd al-Wahhâb adalah perlawanan orang-orang Wâșilîyah, penganut aliran Mu'tazilah. Karena sebagian besar mereka keturunan Yifrin, suku Ibn Fandîn, maka mereka menuntut balas terhadap kematian Ibn Fandîn. Upaya damai telah dilakukan, tetapi perang tetap tidak d:apat dihindari. Pertempuran berakhir dengan kekalahan kelompok Wâșilîyah. ${ }^{30}$ Selanjutnya, muncul pemberontakan Banû Massâlah dari suku Hawwârah yang merasa keinginan mereka untuk mempererat hubungan dengan suku Lawâtah melalui pernikahan dihalang-halangi oleh 'Abd al-Wahhâb. Akibatnya, pertempuran meletus dan perlawanan itu dapat dipadamkan pemerintah. ${ }^{31}$

Banyaknya polemik yang dihadapi 'Abd al-Wahhâb tidak menghalanginya untuk menyukseskan pemerintahannya. Kesuksesan 'Abd al-Wahhâb terbukti dengan pemulihan stabilitas pemerintahan dan perwujudan kesejahteraan masyarakat. Tidak hanya itu, pengaruh 'Abd al-Wahhâb juga berdampak di luar negerinya, yakni dengan pengepungan Tripolitania dan penguasaan Tilimsân. Bukti keberhasilan lainnya adalah loyalitas masyarakat Jabal Nafûsah yang menjadi pilar utama bagi kelangsungan pemerintahan Ibâdîyah pada saat itu. ${ }^{32}$ Persoalan yang masih tersisa hanyalah mengenai penegasian Khalaf b. al-Samh yang tetap bersikukuh menjadi penerus ayahnya sebagai penguasa Jabal Nafûsah. ${ }^{33}$ Penentangan Khalaf tersebut barangkali turut dipicu oleh peralihan kekuasaan secara turun-

\footnotetext{
28 Ibn al-Ṣaghîr, Akbbâr, 43.

29 al-Bârûnî, al-Ažhâr, Vol. 2, 152-166.

${ }^{30}$ Ibid., 175-177.

31 Ibn al-Ṣaghîr, Akbbâr, 52-55.

32 Ibid., 45.

33 al-Bârûnî, al-Ažhâr, Vol. 2, 201-209.
} 
temurun di dalam pemerintahan Rustamîyah dari 'Abd al-Rahmân kepada anaknya, 'Abd al-Wahhâb. Pemerintahan 'Abd al-Wahhâb berakhir pada tahun $211 \mathrm{H}(826 \mathrm{M})$ ketika ia meninggal. ${ }^{34} \mathrm{Di}$ antara faktor yang menunjang keberhasilan pemerintahannya adalah kemampuan kepemimpinan 'Abd al-Wahhâb yang telah ditempa oleh ayahnya semenjak masa perjuangan Ibâdîyah dalam mendirikan Dinasti Rustamîyah dan selama menjalankan kekuasaan politik. ${ }^{35}$

3. Aflah b. 'Abd al-Wahhâb (211-240 H/826-854 M)

Aflah b. 'Abd al-Wahhâb menggantikan kedudukan ayahnya, di mana ia dicalonkan oleh ayahnya setelah ia berhasil memadamkan perlawanan Banû Massâlah karena rencana pernikahan mereka dengan suku Lawâtah digagalkan 'Abd al-Wahhâb. ${ }^{36}$ Sebelumnya, ia juga mampu menumpas pemberontakan Ibn Fandîn. ${ }^{37}$ Permasalahan yang dihadapinya adalah polemik yang sudah muncul semenjak masa pemerintahan ayahnya dan belum dapat diselesaikan saat itu, yaitu penentangan Khalaf b. al-Samh yang tetap mempertahankan posisinya sebagai penguasa Jabal Nafûsah meneruskan kepemimpinan ayahnya, al-Samh. Karena tindakan persuasif pemerintahan Aflạ tidak membawa hasil signifikan dan justru menjadikan Khalaf semakin berani, maka peperangan terpaksa dilakukan. Dalam peperangan yang dipimpin al-'Abbâs b. Ayyûb, pasukan Rustamîyah mampu mengalahkan pasukan Khalaf. Setelah itu, timbul penentangan Faraj al-Nafûsî yang terkenal dengan Naffât (Naffâth) b. Naṣr terhadap keputusan Aflah yang mengangkat Sa'd b. Abî Yûnus sebagai penguasa daerah Qanțarârah meneruskan tampuk kekuasaan ayahnya. Aflah menilai skill dan intelektualitas $\mathrm{Sa}^{\mathrm{c} d}$ jauh lebih mumpuni ketimbang Naffât, sedangkan Naffât sendiri memandang dirinya lebih mampu daripada Sa'd. Setelah sempat melarikan diri ke Baghdad dikarenakan ketakutannya terhadap tindakan keras dan hukuman yang hendak dijatuhkan oleh Aflah kepadanya, ia kemudian memutuskan pulang ke Tahert dan menyatakan tunduk pada pemerintahan Rustamîyah. ${ }^{38}$

\footnotetext{
34 al-Ḥarîrî, al-Dawlah, 128, dan 137-138.

35 Ibid., 111.

${ }^{36}$ Ibn al-Ṣaghîr, Akbbâr, 55.

37 al-Bârûnî, al-Azhâr, Vol. 2, 161.

38 Ibid., 251-267; Ṣâlih Ma'yûf Miftâh, Jabal Nafûsab wa 'Alâqatuh bi al-Dawlah al-

Rustamîyah (Tawalt: Mu'assasah Tawalt al-Thaqâfiyah, 2006), 196-197; dan 'Alî
} 
Selama kepemimpinan Aflah, pemerintahan Rustamîyah bertambah maju. Perdagangan semakin pesat, karena banyak pedagang asing yang singgah di Tahert, dan pemasukan keuangan negara terus meningkat. Kemakmuran dan kesejahteraan masyarakat dapat diwujudkan. ${ }^{39}$ Ketika putera Aflah, Abû al-Yaqzân, menunaikan ibadah haji ke Mekah dan ditahan oleh Dinasti 'Abbâsîyah selama bertahun-tahun, Aflạ mengalami kesedihan mendalam sampai akhirnya ia sakit dan meninggal. ${ }^{40}$ Kematiannya yang terjadi pada tahun $240 \mathrm{H}(854 \mathrm{M})$ itu menandai berakhirnya kepemimpinan Aflah. ${ }^{41}$

\section{Abû Bakr b. Aflah (240-241 H/854-855 M)}

Setelah Aflah wafat, banyak masyarakat yang mendatangi Abû Bakr b. Aflah untuk membaiatnya sebagai pemimpin menggantikan ayahnya, Aflah. Sebenarnya, pada saat itu juga terdapat seruan penolakan terhadap pemilihan Abû Bakr. Namun, seruan tersebut tidak mendapat tanggapan masyarakat. Permasalahan pertama yang dihadapi Abû Bakr adalah berkaitan dengan Muhammad b. 'Irfah. Sosok ini pernah menjadi utusan Aflah dalam urusan luar negeri. Selain itu, ia menikahi saudara perempuan Abû Bakr, dan sebaliknya Abû Bakr menikahi saudara perempuan Ibn 'Irfah. Karena kedekatan hubungan mereka berdua inilah, Ibn 'Irfah dapat memperoleh dukungan cukup besar di lingkaran Dinasti Rustamiyah. Pemegang kendali secara nyata berada di tangan Ibn 'Irfah, sedangkan Abû Bakr sekadar formalitas nama. Kondisi semacam inilah yang pada perkembangannya menimbulkan persoalan pelik dan konflik pada Dinasti Rustamîah di kemudian hari. Konflik itu terjadi setelah Ibn 'Irfah terbunuh dan masyarakat luas mengarahkan tuduhan kepada Abû Bakr sebagai orang yang berada di balik peristiwa tersebut. ${ }^{42}$

Karena Abû Bakr tidak mampu menyelesaikan konflik yang telah memecah belah masyarakat Ibâdîyah tersebut, pemerintahan yang berada di bawah kepemimpinannya mengalami kegagalan dan kekuasaannya tidak berlangsung lama. Saat itu Abû Bakr justru

Muhạmmad al-Ṣallâbî, Șafahâat Mushriqah min al-Târîkh al-Islâmî fì al-Shimâl al-Ifrîqû, Vol. 1 (Kairo: Dâr Ibn al-Jawzî, 2007), 410.

${ }^{39}$ Ibn al-Ṣaghîr, Akhbâr, 61-62.

40 Ibid., 64-69.

41 al-Ḥarîrî, al-Dawlah, 154.

${ }^{42}$ Ibn al-Ṣaghîr, Akbbâr, 70-75. 
melarikan diri beserta orang-orang kepercayaannya mengamankan diri dengan keluar dari Tahert. Informasi mengenai perjalanan hidup Abû Bakr setelah kisruh politik itu tidak diketahui dan tidak disebutkan dalam literatur sejarah. ${ }^{43}$ Stabilitas pemerintahan Rustamîah dapat kembali terwujud pada tahun $241 \mathrm{H}(855 \mathrm{M})$ setelah diambil alih oleh Abû al-Yaqzân Muhammad, saudara Abû Bakr. ${ }^{44}$

5. Abû al-Yaqzân b. Aflah (241- 281 H/855-894 M)

Abû al-Yaqzân sebenarnya orang yang paling diharapkan untuk menjadi pemimpin Dinasti Rustamîyah menggantikan Aflah. Karena Abû al-Yaqzân tidak berada di Tahert saat ayahnya meninggal dunia, maka terpilihlah Abû Bakr. Saat itu, posisi Abû al-Yaqzân sedang berada dalam penjara di Baghdad. Ibn al-Ṣaghîr tampak ragu-ragu ketika menerangkan siapa nama khalifah 'Abbâsîyah yang memenjarakan Abû al-Yaqzân. Dalam penuturannya, ia menyebutkan Khalifah al-Mutawakkil atau lainnya. Menurut Ibrâhîm Bahâa (penyunting buku Ibn al-Ṣaghîr), Abû al-Yaqzân dipenjara bersamasama dengan al-Mutawakkil pada masa pemerintahan Khalifah alWâthiq, saudara al-Mutawakkil. ${ }^{45}$ Al-Wâthiq tidak menginginkan alMutawakkil menjadi khalifah. ${ }^{46}$ Di dalam penjara inilah, Abû alYaqzân dan al-Mutawakkil menjalin persahabatan. Setelah al-Wâthiq terbunuh dan digantikan oleh al-Mutawakkil, Abû al-Yaqzân dibebaskan dari tahanan. Selama bebas dari tahanan sampai keluar dari Baghdad menuju Tahert, ia diperlakukan dengan baik. AlMutawakkil telah memerintahkan wazîr-nya untuk menghormati dan menjaga keselamatan Abû al-Yaqzân. ${ }^{4}$

Abû al-Yaqzân pulang ke Tahert ketika kepemimpinan Rustamîyah sudah berganti dari Aflah, ayahnya, kepada Abû Bakr, saudaranya. Sebagai sosok yang tidak berambisi terhadap kekuasaan, Abû al-Yaqzân tidak berusaha mengambil alih tampuk kepemimpinan saudaranya. Ia justru loyal dalam membantu pemerintahan Abû Bakr. Kesehariannya diisi dengan pelayanan masyarakat secara ikhlas

\footnotetext{
43 Ibid., 84-85.

44 al-Ḥarîrî, al-Dawlah, 166.

45 Ibn al-Ṣaghîr, Akbbâr, 64-65.

${ }^{46}$ Hẹasan Ibrâhîm Hasan, Târîkh al-Islâm al-Siyâsî wa al-Dînî wa al-Thaqâfî̀ wa al-Ijtimâû, Vol. 3 (Kairo: Maktabat al-Nahḍah al-Mișrîyah, 1964), 4.

${ }^{47}$ Ibn al-Ṣaghîr, Akbbâr, 65-69.
} 
sehingga Abû Bakr, para tokoh Ibâdîyah, dan masyarakat luas merasa senang. Semua orang memuji kecakapan Abû al-Yaqzân. ${ }^{48}$

Ketika terjadi kekisruhan politik berkaitan dengan persoalan Muhammad b. 'Irfah di Tahert, Abû al-Yaqzân pada awalnya masih dapat bersikap netral dengan tidak melibatkan diri terlalu jauh di dalam konflik. Ia kemudian diminta masyarakat, terutama orang-orang Nafûsah, untuk menyelesaikan persoalan politik tersebut, di mana ia kemudian berhasil meredam konflik itu dan menjadi pemimpin Rustamîyah menggantikan Abû Bakr. ${ }^{49}$ Jasa terpenting yang disumbangkan Abû al-Yaqzân adalah menciptakan stabilitas politik di Tahert setelah sempat terkoyak sebelumnya. Berkat kepribadian dan kepiawaiannya dalam memimpin, kondisi Tahert kembali kondusif. Ia mempunyai sifat mulia yang mirip sekali dengan 'Abd al-Raḥmân b. Rustam, pendiri Dinasti Rustamîyah. Ia merupakan sosok yang zuhud dan ahli ibadah. Ia berhasil menyemarakkan kehidupan intelektual di Tahert. Pada masa kepemimpinannya, banyak ulama dari berbagai mazhab keagamaan bermunculan, baik Ibâdîyah maupun nonIbâdîyah. Semua aliran agama diberi kesempatan untuk tumbuh dan berkembang. Di antara ulama-ulama tersebut adalah 'Îsâ b. Firnâs, Maḥmûd b. Bakr, 'Abd Allâh b. al-Lamṭî, dan Abû 'Ubaydah alA ${ }^{6}$ raj. ${ }^{50}$ Kepemimpinannya berjalan dengan baik selama empat puluh tahun sampai tahun $281 \mathrm{H}$ (894 M) ketika ia meninggal. ${ }^{51}$

6. Abû Hâatim Yûsuf b. Abî al-Yaqzân (281-294 H/894-906 M)

Abû al-Yaqzân mempunyai beberapa putera, di antaranya ialah alYaqzân, Abû Hậtim Yûsuf, Abû Khâlid, 'Abd al-Wahhâb, dan Wahb. Sepeninggal Abû al-Yaqzân, masyarakat memilih Abû Hâtim untuk menggantikan kedudukan ayahnya. Abû Hâtim mempunyai ibu bernama Ghazâlah yang sangat berpengaruh kuat di lingkungan pemerintahan Abû al-Yaqzân. ${ }^{52}$ Dominasi perempuan terhadap kebijakan pemerintah semacam inilah yang mungkin turut memperlemah Dinasti Rustamîyah, sebagaimana terlihat pada dinastidinasti lain sepanjang sejarah Islam. Misalnya yang dijumpai dalam pemerintahan Khalifah Hârûn al-Rashîd yang terpengaruh istrinya,

\footnotetext{
${ }^{48}$ Ibid., $72-73$.

49 Ibid., 87.

50 Ibid., 92-97.

51 Ibid., 92, dan 102.

52 Ibid., 102-103.
} 
Zubaydah Umm Ja'far, dalam menetapkan al-Amîn b. Zubaydah sebagai putra mahkota, meskipun al-Amîn kurang memiliki kapabilitas untuk menjalankan pemerintahan. ${ }^{53}$

Ketika Abû al-Yaqzân meninggal, kedua puteranya yang paling unggul di antara anak-anaknya yang lain tidak berada di Tahert. AlYaqzân sedang melaksanakan ibadah haji, sedangkan Abû Hâtim sedang ditugasi ayahnya supaya memimpin pasukan untuk melindungi kafilah dagang yang datang dari kawasan Mashriq terhadap ancaman gangguan dari suku Zanâtah. Masyarakat waktu itu menetapkan pilihan kepada Abû Hâtim untuk menggantikan kepemimpinan ayahnya. Mereka langsung mengarak Abû Hâtim menuju masjid dan membaiatnya menjadi pemimpin pada saat ia sampai di Tahert. ${ }^{54}$

Persoalan pertama yang dihadapi pemerintahan Abû Hâtim adalah pemberontakan yang digerakkan oleh Muhammad b. Rabbâh dan Muhammad b. Hamâd. Keduanya berupaya menggulingkan Abû Hâtim, sehingga ia terpaksa meninggalkan Tahert menuju benteng Lawâtah. Kepergian Abû Hậtim saat itu untuk menghimpun kekuatan, maka setelah kekuatan terkumpul dan persiapan dirasa memadai, pasukan Abû Hâtim pun menyerang Tahert dari beberapa arah sekaligus. Tatkala penduduk Tahert mulai terdesak, mereka bersepakat menemui Yađqûb b. Aflaḥ, paman Abû Hâtim. Keinginan warga Tahert itu disetujui oleh Ya'qûb. Semenjak pengangkatan Abû Hâtim sebagai penguasa, hubungan Abû Hâtim dengan pamannya kurang harmonis. Ya'qûb pindah ke Zawâgah dan tidak peduli terhadap permasalahan pemerintahan Abû Hậtim. Selanjutnya, peperangan beralih antara Abû Hâttim dengan Ya'qûb. Peperangan internal Rustamîyah dan pengepungan pasukan Abû Hâatim terhadap Tahert itu berakhir dengan gencatan senjata. Pelopor perdamaian itu ialah Abû Ya'qûb al-Mazâtî, seorang tokoh Mazâtah.

Kedua kubu yang berseteru menyepakati untuk menghentikan pertempuran selama empat bulan. Selama masa tenang tersebut, dukungan dan simpati masyarakat Tahert kepada Abû Hâtim semakin bertambah. Ya'qûb dan para pendukungnya ternyata tetap menjauhi Abû Hâatim. Berkat dukungan masyarakat Tahert itu, Abû Hậtim dapat kembali berkuasa di Tahert. Rentang waktu antara kepergian

53 Aḥmad Shalabî, Mawsû́at al-Târîkh al-Islâmî wa al-Hadârah al-Islâmîyah, Vol. 2 (Kairo: Maktabah al-Nahḍah al-Miṣrîyah, 1984), 157, dan 169.

${ }^{54}$ Ibn al-Ṣaghîr, Akhbâr, 104-105. 
Abû Hâatim dari Tahert dan kepulangan ke kota itu berlangsung sekitar empat tahun. ${ }^{55}$ Setelah kembali berkuasa pada tahun $284 \mathrm{H}$ (897 M), Abû Hâtim memperbaiki kondisi pemerintahan dan kehidupan masyarakat yang mengalami kemunduran selama konflik politik. Namun, persoalan lain kembali muncul lagi, di mana masa pemerintahan Abû Hâtim ini, al-Tayyib b. Khalaf memberontak di wilayah Jabal Nafûsah. Al-Tayyib adalah putera Khalaf b. al-Samh yang sebelumnya pernah bermusuhan dengan Rustamîah semenjak kepemimpinan 'Abd al-Wahhâb b. 'Abd al-Raḥmân, disebabkan sikapnya yang ingin meneruskan kedudukan al-Samh. Perlawanan alTayyib dapat dipadamkan pemerintah melalui penangkapan yang dipimpin oleh Abû Manșûr Ilyâs. ${ }^{56}$

Sementara itu, pada masa kepemimpinan Abû Hâtim pula terjadi malapetaka besar yang dialami Dinasti Rustamiyah, yakni kekalahan Rustamîyah pada tahun 283 H (896 M) dalam Perang Mânû di Jabal Nafûsah tatkala berhadapan dengan Dinasti Aghlabîyah yang dipimpin oleh Ibrâhîm b. Aḥmad al-Aghlabî. Ibrâhîm saat itu melewati Jabal Nafûsah dan melakukan banyak tindakan kezaliman sepanjang perjalanan. Oleh karena itu, Aflah b. al-'Abbâs (penguasa Jabal Nafûsah) dan pasukannya hendak menghentikannya. Kekuatan Aghlabîyah terlalu tangguh bagi Rustamîyah sehingga Aghlabîyah dapat menghancurkan pasukan Nafûsah dengan mudah. ${ }^{57}$ Pemerintahan Rustamîyah yang dikendalikan oleh Abû Hâtim berakhir pada tahun $294 \mathrm{H}$ (906 M) ketika terjadi pembunuhan terhadap dirinya. ${ }^{58}$

7. Al-Yaqzân b. Abî al-Yaqzâan (294-296 H/906-909 M)

Kepemimpinan Dinasti Rustamîyah selanjutnya diteruskan oleh al-Yaqzân b. Abî al-Yaqzân. Peralihan kekuasaan dari Abû Hậtim kepada al-Yaqzân, saudaranya, yang diwarnai pembunuhan terhadap Abû Hâtim, menyebabkan banyak masyarakat yang tidak menyukai alYaqz̧ân. Mereka meyakini keterlibatan al-Yaqz̧ân dalam konspirasi pembunuhan terhadap Abû Hâtim. Akibatnya, pemerintahan alYaqzân tidak dapat berjalan mulus. Tidak hanya itu, pada masa kepemimpinannya ancaman kelompok Shî‘ah terhadap Dinasti

55 Ibid., 105-115; dan al-Bârûnî, al-Az̧hâr, Vol. 2, 333-337.

56 al-Harîrî, al-Dawlah, 176-180.

${ }^{57}$ al-Bârûnî, al-Az̧hâr, Vol. 2, 342-343; dan Ibn 'Idhârî, al-Bayân, Vol. 1, 129.

58 al-Bârûnî, al-Ažhâr, Vol. 2, 354. 
Rustamîyah semakin mendekat. Dengan dipimpin oleh Abû 'Abd Allâh al-Husayn al-Shî̂î, pasukan Shî'ah berhasil mengalahkan pasukan al-Yaqzân.

Al-Shî̀ adalah juru dakwah dan sekaligus panglima perang kelompok Shî‘ah Ismầ̂lîyah yang mendirikan Dinasti Fạtimîyah di bawah kendali 'Ubayd Allâh al-Mahdî. Pada bulan Syawwâl $296 \mathrm{H}$ (Juni 909 M) kelangsungan Dinasti Rustamîah berakhir. Pasukan Shî‘ah membunuh al-Yaqzân dan membantai masyarakat Tahert. Mereka juga merusak dan membakar perpustakaan al-Ma'ṣ̂mah di Tahert yang menyimpan banyak koleksi referensi berharga. Setelah tragedi berdarah itu, masyarakat Ibâdîyah menemui Ya'qûb b. Aflạ yang sedang dalam perjalanan menuju Wârjalân. Mereka memohon kepada Yacqûb supaya bersedia memimpin masyarakat Ibâdîyah untuk mendapatkan kembali kekuasaan Ibâdîyah yang hilang. Permohonan mereka tidak dikabulkan oleh Ya'qûb. Situasi sudah tidak memungkinkan bagi Ibâdîyah untuk mengembalikan kekuasaan politik mereka. ${ }^{59}$

Itulah episode terakhir pemerintahan Rustamîyah yang berujung pada kehancuran diakibatkan tindakan brutal yang dikoordinir musuhmusuh Rustamîyah di bawah kendali al-Shî̀î. Menurut Shaban,

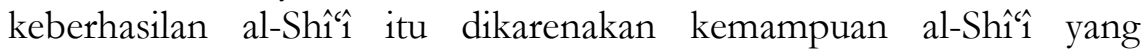
mengorganisasi kekuatan suku Kutâmah dari masyarakat Berber secara baik untuk mendukung gerakan 'Ubaid Allâh al-Mahdî́ ${ }^{60}$ setelah pada 7 Rajab 296 H (31 Maret 909 M) dibebaskan dari penjara Ilyasa b. Midrâr, penguasa Dinasti Midrârîyah, di Sijilmâsah. ${ }^{61}$

Konon, penahanan al-Mahdî itu dilakukan atas perintah penguasa Aghlabîyah, Ziyâdat Allâh, yang mengirimkan surat kepada Ilyasa‘. ${ }^{62}$ Namun, hal itu sebenarnya tidak menunjukkan adanya peranan dan intervensi Aghlabîyah terhadap Midrârîyah. Penangkapan itu murni dikarenakan Ilyasa' menyadari ancaman gerakan Shî‘ah. Faktor perbedaan ideologis antara Midrârîyah yang bermazhab Khawârij dan

\footnotetext{
${ }^{59}$ Ibid., 357-359.

${ }^{60}$ M. A. Shaban, Islamic History: A New Interpretation, Vol. 2 (Cambridge: Cambridge University Press, 1992), 191; dan Muhammad Jamâl al-Dîn Surûr, Târîkh al-Dawlah al-Fâtimîyah (Kairo: Dâr al-Fikr al-'Arabî, 1995), 22-23.

${ }^{61}$ Ibn 'Idhârî, al-Bayân, Vol. 1, 157; dan Hasan, Târíkh, Vol. 3, 144-145.

62 Mahmûd Ismâ'îl, Al-Aghâlibah: Siyâsatubum al-Khârijîyah (Fez: 'Ayn li al-Dirâsât wa al-Buhûth al-Insânîyah wa al-Ijtimâcîyah, 2000), 96; dan Ameer Ali, A Short History of the Saracens (New Delhi: Kitab Bhavan, 1994), 592-593.
} 
Aghlabîyah yang bermazhab Sunnî, serta faktor politis yang menunjukkan permusuhan Midrârîyah dengan 'Abbâsîyah (sekutu Aghlabîyah) jelas menjadi penghalang bagi keduanya untuk menjalin hubungan persahabatan. ${ }^{63}$ Dengan kehancuran Rustamîyah, berakhir pula kekuasaan politik Ibâdîyah di kawasan Maghrib yang telah memperlihatkan kemajuan peradabannya. Di antara penyebab kehancuran itu disebabkan konflik internal yang merapuhkan kekuatan Rustamiyah. Selain itu, dipengaruhi pula oleh ketiadaan pasukan reguler Rustamîyah yang mengakibatkan pihak asing semakin mudah melakukan penyerangan, meskipun Rustamîah sudah mempunyai para agen intelijen untuk mengantisipasinya. ${ }^{64}$

\section{Kebijakan Toleransi Beragama}

Kebijakan Dinasti Rustamîah terhadap orang-orang yang bukan penganut Ibâdîyah, baik dari kalangan umat Islam maupun selain umat Islam, didasari oleh semangat toleransi yang sangat tinggi. Sikap demikian telah ditunjukkan semenjak pemimpin pertama Rustamîyah hingga pemimpin terakhir yang memberikan kesempatan kepada setiap orang untuk hidup damai di wilayah kekuasaan Rustamiyah dengan latar belakang agama yang beraneka ragam. Sebagaimana telah disebutkan sebelumnya, 'Abd al-Raḥmân b. Rustam, pendiri Dinasti Rustamîah dan pemimpin pertama, sangat terkenal sebagai pribadi yang zuhud, jujur, dan adil. Ia berhasil melaksanakan kepemimpinan yang dapat memuaskan semua lapisan masyarakat. Semenjak menempati posisi kedudukannya, ia mencurahkan perhatiannya pada kesejahteraan rakyatnya sehingga kondisi kehidupan warga semakin makmur. Berkat kepemimpinannya pula, banyak pendatang dari luar wilayah Rustamiyah yang berkunjung ke Tahert dan berdomisili di sana. Mereka berasal dari berbagai wilayah, di antaranya Bashrah dan Kufah. Saat itu, pemerintah juga mendapatkan pemasukan jizyah dari masyarakat selain umat Islam. Selain dikarenakan ketertarikan mereka kepada keadilan pemimpin Rustamîyah, mereka datang ke Tahert untuk menjalankan bisnis perdagangan. Kemakmuran inilah yang menyebabkan pemerintahan Rustamîyah menolak pemberian bantuan finansial orang-orang Ibâdîyah dari kawasan Mashriq yang hendak menyerahkan bantuan mereka untuk pengiriman yang kedua kalinya. ${ }^{65}$

\footnotetext{
${ }^{63}$ Ismầ̂̀l, al-Aghâlibah, 96.

${ }^{64}$ Jahlân, al-Fiker, 127; al-Harîrî, al-Dawlah, 228; al-Bârûnî, al-Azhâr, Vol. 2, 239; dan Lapidus, $A$ History, 371.

${ }^{65}$ Ibn al-Ṣaghîr, Akbbâr, 36-37, dan 41.
} 
Pemerintahan 'Abd al-Wahhâb melanjutkan kebijakan 'Abd alRaḥmân. Kesejahteraan masyarakat semakin meningkat, ${ }^{66}$ meskipun saat itu terdapat perselisihan politik antara pemerintah Ibâdîyah dan komunitas Mu'tazilah Wâșilîyah. ${ }^{67}$ Demikian pula, pemerintahan Aflah b. 'Abd al-Wahhâb yang mampu mewujudkan kemakmuran berlimpah dengan ditandai pesatnya pembangunan fisik dan maraknya aktivitas perdagangan, baik yang dilakukan oleh para pedagang domestik maupun mancanegara. ${ }^{68}$ Hubungan sosial kemasyarakatan tersebut sempat terusik ketika terjadi konflik internal pada masa pemerintahan Abû Bakr b. Aflah.. ${ }^{99}$ Setelah stabilitas pemerintahan Rustamîyah dapat dipulihkan kembali di bawah kepemimpinan Abû al-Yaqzân b. Aflah, kehidupan damai di kalangan masyarakat yang plural tersebut berjalan normal dengan penuh ketenangan seperti sediakala. Abû al-Yaqzân sering menyelenggarakan munâzarah atau forum diskusi yang diikuti berbagai tokoh aliran Islam di lingkungan istananya, misalnya antara Ibâdîyah dan Mu'tazilah. Ibn al-Ṣaghîr, sejarawan yang menganut mazhab Shî'ah, pernah mengikuti secara langsung suatu pertemuan antara Abû al-Yaqzân dan masyarakat yang dipimpinnya. ${ }^{70}$

Keadaan serupa yang diliputi suasana kerukunan dan keharmonisan juga dijumpai pada masa kepemimpinan Abû Hâtim. Diskusi-diskusi ilmiah tetap diadakan, bahkan saat itu terdapat beberapa pemuka non-Ibâḍ̂yah yang dekat dengan Abû Hâatim. Misalnya, Abû Mas'ûd, Abû Danwan, dan 'Ulwân b. 'Ulwân berasal dari Kufah yang beraliran Hanafî. Tidak hanya itu, Abû Hâtim ketika memutuskan suatu permasalahan pemerintahan sering bermusyawarah dengan para tokoh masyarakat, baik dari kalangan Ibâdîyah maupun selain Ibâdîyah. ${ }^{71}$ Pemerintahan terakhir yang dipimpin al-Yaqzân b. Abî al-Yaqzân masih tetap memberikan kebebasan kepada semua masyarakat dari berbagai aliran keagamaan yang berbeda-beda. Kondisi semacam inilah yang turut merugikan pemerintahan Rustamîah, yakni pada saat-saat keruntuhan Rustamîyah banyak pihak dari luar Ibâḍ̂yah yang mendukung Abû

66 Ibid., 45.

${ }^{67}$ al-Bârûnî, al-Ažhâr, Vol. 2, 175-177; dan al-Ḥarî̀î, al-Dawlah, 119-123.

${ }^{68}$ Ibn al-Ṣaghîr, Akbbâr, 61-62.

${ }^{69}$ Ibid., 83.

${ }^{70}$ Ibid., 92-94.

${ }^{71}$ Ibid., 105, dan 116-117.

160 ISLAMICA, VOLUME 8, NOMOR 1, SEPTEMBER 2013 
'Abd Allâh al-Shî̂î dalam menghancurkan Rustamîyah dan menghabisi riwayat al-Yaqzân.

Orang-orang tersebut di antaranya berasal dari aliran Shî‘ah, Mu'tazilah Wâșilîyah, dan Șufrîyah. ${ }^{72}$ Masyarakat Shî‘ah, Mu'tazilah, dan Șufrîyah yang turut menikmati kebebasan beragama di wilayah Rustamîyah tersebut justru ikut serta dalam penggulingan Rustamîyah. Hal itu mungkin disebabkan mereka telah menyaksikan kondisi pemerintahan Rustamîyah yang sudah sangat rapuh dan berada di bibir jurang kehancuran. Mereka tentunya mengetahui masyarakat Nafûsah yang merupakan pilar penting eksistensi Rustamîyah pada tahun $283 \mathrm{H}(896 \mathrm{M})$ telah dikalahkan dan dihancurkan oleh pasukan Dinasti Aghlabîyah dalam pertempuran Mânû. ${ }^{73}$

Pemaparan di atas jelas memperlihatkan pemerintahan Rustamîyah yang semenjak awal pembentukannya hingga akhir kehancurannya mampu menerapkan kebijakan toleransi kepada setiap orang tanpa memandang aliran yang dianutnya. Perbedaan suku, bangsa, dan agama di antara manusia merupakan keniscayaan dan sunnatullah yang tidak dapat dihindari. ${ }^{74}$ Karena pluralitas keberagamaan manusia telah menjadi ketentuan Allah, maka sikap yang semestinya dilakukan adalah mengakui dan menerima perbedaan tersebut dalam suasana keharmonisan. Berkaitan dengan perbedaan agama, Allah memberikan tuntunan untuk mengedepankan toleransi dengan senantiasa bersikap saling menghormati di antara pemeluk agama yang beraneka ragam itu. ${ }^{75}$

Kebijakan toleransi Rustamiyah sangat sejalan dengan kebijakan politik yang telah diteladi dari Rasulullah selama memimpin umat Islam. Bukti historis yang masih dapat ditemui terkait dengan pelaksanaan toleransi beragama tersebut adalah keberadaan Dustûr alMadinah (Piagam Madinah atau Konstitusi Madinah). Piagam ini merupakan konstitusi pertama yang dikenal umat manusia. Dari piagam ini terungkap beberapa informasi yang intisarinya sebagai berikut. Masyarakat pendukung piagam ini adalah masyarakat yang

\footnotetext{
72 al-Bârûnî, al-Az̧hâr, Vol. 2, 358.

${ }^{73}$ Ibid., 342-343.

${ }^{74}$ Lihat surah al-Hujurât ayat 13.

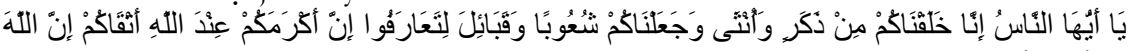
عَلِيمُ خَيِيرُ.

${ }^{75}$ Lihat surah al-Kâfirûn ayat 1-6.

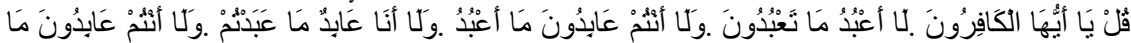

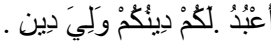


majemuk. Ikatan persatuan mereka bersifat politis demi meraih citacita bersama. Masyarakat yang dikelompokkan menjadi dua kategori, yakni Muslim dan non-Muslim, harus memiliki solidaritas tinggi. Negara melindungi kebebasan menjalankan ibadah agama. Semua orang mempunyai kedudukan yang sama sebagai anggota masyarakat. Hukum harus ditegakkan dan semua orang diperlakukan sederajat di hadapan hukum. Mereka wajib saling tolong menolong dan dilarang melakukan perbuatan buruk. Setiap warga memiliki hak dan kewajiban yang sama terhadap negara. Tradisi atau kebiasaan masa lalu tetap diberlakukan dengan berpedoman pada keadilan dan kebenaran. Setiap orang mempunyai hak yang wajib dihormati. ${ }^{76}$

Teladan toleransi juga dicontohkan oleh Khalifah 'Umar b. alKhattâb pada tahun 15 H (636 M) tatkala menerima penyerahan Îliyâ' (Bayt al-Maqdis). Dalam perjanjian perdamaian ditegaskan sebagai berikut. Penduduk Îliyâ' berhak mendapatkan perlindungan dan jaminan keamanan atas harta, jiwa, gereja, salib, para tawanan, penduduk sipil, dan semua ajaran agama mereka. Gereja mereka tidak boleh diduduki dan dirusak, termasuk tanah gereja, salib, dan semua kekayaan gereja mereka. Mereka tidak boleh dipaksa meninggalkan agama mereka dan tidak boleh dianiaya. Penduduk Îliyâ' diwajibkan membayar jiżyah seperti penduduk Madâ'in. Penduduk Îliyâ' diberi wewenang mengeluarkan bangsa Romawi dari wilayahnya. Siapa saja di antara mereka yang keluar dari wilayah Îliyâ' dilindungi jiwa dan hartanya hingga sampai ke tempat tujuannya. Barangsiapa di antara mereka yang ingin tinggal di Îliyâ' diperbolehkan dengan kewajiban sama seperti penduduk Illiyâ', yaitu membayar jizyyah. Penduduk Îliyâ' yang ingin meninggalkan Îliyâ' dan ikut bangsa Romawi dengan membawa harta benda dan salib mereka harus dilindungi hingga sampai ke tujuan mereka. Siapa saja dari wilayah lain yang berada di Îliyâ' diberikan hak untuk tinggal di sana dengan kewajiban membayar jizyah sebagaimana penduduk Îliyâ', atau ikut bangsa Romawi, atau kembali ke wilayah asalnya. Penduduk Îliyâ' tidak ditarik pungutan hingga mereka menuai hasil panennya. Semua isi surat tersebut adalah merupakan perjanjian Allah dan menjadi jaminan Rasul-Nya, para khalifah, dan semua umat Islam selama mereka membayar jizyah. ${ }^{77}$

${ }^{76}$ Ḥasan, Târikkh, Vol. 1, 101-102; dan Nourouzzaman Shiddiqi, Jeram-jeram Peradaban Muslim (Yogyakarta: Pustaka Pelajar, 1996), 93-94.

77 Abû Ja'far Muhammad b. Jarîr al-Ṭabarî, Târîkh al-Ṭabarî: Târîkh al-Umam wa alMulûk, Vol. 2 (Beirut: Dâr al-Kutub al-'Ilmîyah, 2005), 449. 
Pada masa pemerintahan Rustamîyah, semua masyarakat yang mempunyai kecenderungan keagamaan berbeda mempunyai kesempatan yang sama untuk tinggal dan hidup berdampingan secara damai penuh kerukunan. Meskipun mereka menghargai perbedaan ideologi, tetapi para ulama Ibâdîyah tetap konsisten melakukan pembelaan terhadap pandangan-pandangan teologis yang mereka yakini kebenarannya. Mereka menanggapi pendapat dan pemikiran mazhab lain melalui perdebatan lisan maupun melalui penulisan karya tulis untuk mempertahankan pemikiran mereka. Misalnya ialah sikap yang dilakukan oleh Mahdî al-Nafûsî, Abû al-Yaqzân b. Aflah, 'Abd Allâh al-Lamṭ̂, dan Maḥmûd b. Bakr. ${ }^{78}$ Masyarakat non-Muslim juga mendapatkan kebebasan beraktivitas. Pada saat itu terdapat pakar bahasa beragama Yahudi bernama Yahûdhâ b. Quraysy yang telah menyusun buku perbandingan bahasa antara bahasa Arab, Hebrew, dan Berber. ${ }^{79}$ Tidak hanya itu, keberadaan penganut agama Kristen dijumpai pula di Tahert. ${ }^{80}$

Karena Rustamîah memberikan kesempatan kepada seluruh masyarakat yang latar belakangnya beraneka ragam untuk beraktivitas sesuai dengan ketentuan sharî́ah dan peraturan pemerintah, maka Rustamîyah akhirnya berhasil mewujudkan peradaban, terutama di bidang ekonomi. Tahert kemudian mendapat julukan 'Trâq al-Maghrib, al-Irâq al-Saghîr atau Balkh al-Maghrib. Penyebutan itu dikarenakan peradaban Tahert yang menyerupai Irak, pusat pemerintahan 'Abbâsîyah. Irak dan Balkh merupakan dua kota yang sering dijadikan ikon suatu kemajuan peradaban. Irak dilalui Sungai Euphrat dan Sungai Tigris yang membawa berkah melimpah. ${ }^{81}$ Balkh adalah titik pertemuan jalur perdagangan dari India, Cina, Turkistan, dan Iran. Aktivitas perdagangan sutera yang berasal dari Cina melewati kota ini. Dengan posisi geografis yang menguntungkan itu, ia menjadi kota sangat maju yang berperan penting secara ekonomis. ${ }^{82}$ Di samping itu, kemiripan Tahert dan Irak terletak pada kesuburun tanahnya dan

\footnotetext{
78 al-Bârûnî, al-Az̧hâr, Vol. 2, 112, 175, 299, dan 302.

${ }^{79}$ al-Harîrî, al-Dawlah, 237-238.

80 Ibid., 160.

81 al-Bârûnî, al-Az̧hâr, Vol. 2, 49; dan al-Hạarîrî, al-Dawlah, 234.

${ }^{82}$ R. N. Frye, "Balkh", dalam H. A. R. Gibb, J. H. Kramers, E. Levi-Provencal, dan J. Schacht (eds.), The Encyclopaedia of Islam, Vol. 1 (Leiden: E. J. Brill, 1960), 10001001; dan Ferdinand Tawtal, et al., al-Munjid fì al-A lâm (Beirut: Dâr al-Mashriq, 1996), 134.
} 
kemajemukan masyarakatnya yang terdiri dari berbagai bangsa serta menganut agama berbeda-beda. ${ }^{83}$

Dinasti Rustamîyah benal-benar secara konsisten menjalankan ajaran Ibâdîyah yang memandang kesetaraan derajat seluruh kaum Muslim, tanpa memilah-milah aliran yang dianutnya. Menurut tuntunan Ibâdîyah, orang-orang Islam di luar kelompok mereka tidak dinilai kafir selama mereka tidak menyekutukan Allah. Oleh karena itu, Ibâdîyah memperbolehkan para pengikutnya untuk berinteraksi, melakukan persaksian, pewarisan, dan pernikahan dengan kaum Muslim lain yang berbeda pandangan dengan mereka. Sebaliknya, penganut-penganut Ibâdîyah itu dilarang melakukan tindakan kekerasan dan pembunuhan terhadap masyarakat non-Ibâdîyah. ${ }^{84} \mathrm{Jadi}$, motif pemberlakuan kebijakan toleransi tersebut didasarkan pada nilai-nilai ideologis teologis. ${ }^{85}$

\section{Penutup}

Kebijakan toleransi beragama yang diterapkan Dinasti Rustamiyah didasari oleh motif ideologis berlandaskan ajaran Islam dan doktrin Ibâdîyah. Dilihat dari perspektif behavioral appproach, ${ }^{86}$ perilaku politik seluruh pemimpin Rustamiyah sangat konsisten dan teratur dalam melaksanakan tuntunan Ibâdîyah. Penulis tidak menjumpai adanya motif politis di balik kebijakan toleran tersebut. Hal ini berbeda sekali dengan kebijakan toleran yang diterapkan oleh pemerintahan Islam lainnya, misalnya Dinasti Mughal di India pada masa kekuasaan Sultan Jalâl al-Dîn Muhammad Akbar (1556-1605). Saat itu, kebijakan toleransi universal yang dijalankan Akbar bertujuan untuk menciptakan stabilitas politik di wilayahnya. Selain itu, Akbar ingin mewujudkan integrasi antara masyarakat Muslim dan non-Muslim sehingga suasana damai dapat tercipta di bawah kepemimpinannya. Ia bahkan secara radikal menghapuskan jizyah bagi warga non-Muslim

\footnotetext{
83 al-Ḥarîrî, al-Dawlah, 231, dan 234.

${ }^{84}$ al-Isfarâynî, al-Tabsîr, 52-53.

85 Ramlan Surbakti, Memahami Ilmu Politik (Jakarta: Gramedia Widiasarana Indonesia, 1992), 194-195; dan Sartono Kartodirdjo, Pemikiran dan Perkembangan Historiografi Indonesia: Suatu Alternatif (Jakarta: Gramedia, 1982), 55.

86 Pendekatan behavioral menekankan analisis terhadap perilaku politik pemerintah dan proses kebijakannya. Lihat Miriam Budiardjo, Dasar-dasar Ilmu Politik (Jakarta: Gramedia Pustaka Utama, 2002), 5; dan A. Hoogerwerf, Politikologi, terj. R. L. L. Tobing (Jakarta: Erlangga, 1979), 25.
} 
dan menikahi puteri raja-raja Hindu agar dapat menarik simpati kalangan masyarakat Hindu.

Oleh karena itu, kebijakan toleran Akbar terkesan sangat berani mengorbankan sharî́ah Islam, ${ }^{87}$ sedangkan kebijakan toleran Rustamîyah masih tetap mengedepankan tuntunan sharî́ah Islam. Dengan berkaca pada kebijakan toleran Rustamîyah terhadap warganya yang bersifat plural, masyarakat Indonesia yang juga terdiri dari berbagai macam agama dapat menciptakan kehidupan beragama secara harmonis dan selanjutnya mewujudkan kemajuan peradaban sebagaimana pernah dicapai oleh Rustamîah.

\section{Daftar Rujukan}

Ali, Ameer. A Short History of the Saracens. New Delhi: Kitab Bhavan, 1994.

Bârûnî (al), Sulaymân Bâshâ. Al-Ažhâr al-Riyâdîyah A'immah al-Ibâdîyah, Vol. 2. Oman: Saltanah 'Umân, 1987.

Budiardjo, Miriam. Dasar-dasar Ilmu Politik. Jakarta: Gramedia Pustaka Utama, 2002.

Fawzî, Fârûq 'Umar. Al-Imâmah al-Ibâdîyah fì 'Umân. Oman: Jâmi'ah Âli Bayt, 1997.

Frye, R. N. "Balkh", dalam The Encyclopaedia of Islam, H. A. R. Gibb, J. H. Kramers, E. Levi-Provencal, dan J. Schacht (eds.), Vol. 1. Leiden: E. J. Brill, 1960.

Ḥarîrî (al), Muhammad 'Îsâ. Al-Dawlah al-Rustamîyah bi al-Maghrib alIslâmi: Hậârâtubâ wa 'Alâqatuhâ al-Khârijîyah bi al-Maghrib wa alAndalus. Kuwait: Dâr al-Qalam, 1987.

Ḥasan, Ḥasan Ibrâhîm. Târîkh al-Islâm al-Siyâsî wa al-Dînî wa al-Thaqâfî wa al-Ijtimầu, Vol. 3. Kairo: Maktabat al-Nahḍah al-Mișrîyah, 1964.

Hoogerwerf, A. Politikologi, terj. R. L. L. Tobing. Jakarta: Erlangga, 1979.

http://en.wikipedia.org/wiki/Tiaret/diakses 6 Agustus 2012.

'Idhârî, Ibn. al-Bayân al-Mughrib fì Akhbâr al-Andalus wa al-Maghrib, Vol. 1. Leiden: E.J. Brill, 1948.

\footnotetext{
87 Ajid Thohir dan Ading Kusdiana, Islam di Asia Selatan: Melacak Perkembangan Sosial, Politik Islam di India, Pakistan, dan Bangladesh (Bandung: Humaniora, 2006), 9598.
} 
Isfarâynî (al), Abû al-Muzaffar. Al-Tabșîr fì al-Dîn wa Tamyîz al-Firqah al-Nâjiyah 'an al-Firaq al-Hâlikîn. Beirut: Dâr al-Kutub al-'Ilmîyah, 1988.

Ismâ'îl, Maḥmûd. Al-Aghâlibah: Siyâsatuhum al-Khârijîyah. Fez: 'Ayn li al-Dirâsât wa al-Buhụth al-Insânîyah wa al-Ijtimâ'îyah, 2000.

-----. al-Harakât al-Sirrîyah fì al-Islâm. Kairo: Ru'yah, 2006.

Jahlân, 'Adûn. Al-Fiker al-Siyâsî inda al-Ibâdîyah. Seeb: Maktabat alDâmirî, t.th.

Jalî, Aḥmad Muhammad Aḥmad. Dirâsah 'an al-Firaq wa Târîkh alMuslimin: al-Khawârij wa al-Shîah. Riyad: Markaz al-Malik Fayṣal li al-Buhûth wa al-Dirâsât al-Islâmîyah, 1988.

Kartodirdjo, Sartono. Pemikiran dan Perkembangan Historiografi Indonesia: Suatu Alternatif. Jakarta: Gramedia, 1982.

Kenney, Jeffrey T. Muslim Rebels: Kharijites and the Politics of Extremism in Egypt. Oxford: Oxford University Press, 2006.

Khalîfât, 'Iwạ̣ Muhammad. al-Ușûl al-Târîkhîyah li al-Firqah al-Ibâdîyah. Seeb: Wizârat al-Turâth al-Qawmî wa al-Thaqâfah, 1994.

Lapidus, Ira H. A History of Islamic Societies. Cambridge: Cambridge University Press, 1989.

Ma'rûf, Nâyif Maḥmûd. Al-Khawârì fî al-'Așr al-Umawî. Beirut: Dâr alTalî‘ah, 1994.

Makkî (al), Ishâa b. 'Aqîl 'Azûz. Al-Firaq al-Islâmîyah. Beirut: Dâr Ibn Hazm, 1995.

Mernissi, Fetima. Islam and Democracy: Fear of the Modern World, terj. Mary Jo Lakeland. Cambridge: Perseus Publishing, 2002.

Miftâh, Șâliḥ Ma'yûf. Jabal Nafûsah wa 'Alâqatub bi al-Dawlah alRustamîah. Tawalt: Mu'assasah Tawalt al-Thaqâfiyah, 2006.

Mu'ammar, 'Alî Yahyâ. Al-Ibâdị̂ah fî̀ Mawkib al-Târîkh, Vol. 2. Seeb: Maktabat al-Dậmirî, 2008.

Najjâr (al), 'Âmir. al-Ibâdîyah. Kairo: Maktabat al-Thaqâfah al-Dînîyah, 2004.

-----. al-Khawârij: 'Aqîdah wa Fiker wa Falsafah. Kairo: Dâr al-Macârif, 1990.

Nâmî (al), 'Amr Khalîfah. Dirâsât 'an al-Ibâdîyah. Beirut: Dâr al-Gharb al-Islâmî, 2001. 
Nâșir, Muḥammad Șâliḥ dan Shaybânî (al), Sulțân b. Mubârak. Mu'jam Alâm al-Ibâdîyah min al-Qarn al-Awwal al-Hijrî ilâ al-'Aṣr al-Hậdir: Qism al-Mashriq. Beirut: Dâr al-Gharb al-Islâmî, 2006.

Șaghîr (al), Ibn. Akbbâr al-A'immah al-Rustamîyin. Beirut: Dâr al-Gharb al-Islâmî, 1986.

Șallâbî (al), 'Alî Muhammad. Șafahât Mushriqah min al-Târîkh al-Islâmî fî̀ al-Shimâl al-Ifrîqî, Vol. 1. Kairo: Dâr Ibn al-Jawzî, 2007.

Shaban, M. A. Islamic History: A New Interpretation, Vol. 2. Cambridge: Cambridge University Press, 1992.

Shahrastânî (al), Abû al-Fath Muhammad b. 'Abd al-Karîm. Al-Milal wa al-Niḥal, Vol. 1. Beirut: Dâr al-Kutub al-'Ilmîyah, t.th.

Shalabî, Ahmad. Mawsî́ 'at al-Târîkh al-Islâmî wa al-Haḍ̂rah al-Islâmîyah, Vol. 2. Kairo: Maktabah al-Nahḍah al-Mișrîyah, 1984

Shiddiqi, Nourouzzaman. Jeram-jeram Peradaban Muslim. Yogyakarta: Pustaka Pelajar, 1996.

Surbakti, Ramlan. Memahami Ilmu Politik. Jakarta: Gramedia Widiasarana Indonesia, 1992.

Surûr, Muhammad Jamâl al-Dîn. Târîkh al-Dawlah al-Fâtimîyah. Kairo: Dâr al-Fikr al-'Arabî, 1995.

Tabarî (al), Abû Ja'far Muhammad b. Jarîr. Târîkh al-Tabarî: Târîkh alUmam wa al-Mulûk, Vol. 2. Beirut: Dâr al-Kutub al-'Ilmîyah, 2005.

Tawtal, Ferdinand, et al. Al-Munjid fí al-A lâm. Beirut: Dâr al-Mashriq, 1996.

Thohir, Ajid, dan Kusdiana, Ading. Islam di Asia Selatan: Melacak Perkembangan Sosial, Politik. Islam di India, Pakistan, dan Bangladesh. Bandung: Humaniora, 2006.

Zahrah, Muhammad Abû. Târîkh al-Madhâhib al-Islâmîyah fî al-Siyâsah wa al-'Aqâ'id, Vol. 1. Mesir: Dâr al-Fikr al-'Arabî, 1946. 